\title{
The Contribution of Values Education Activities that are Applied in Tirana Haxhi Mahmud Dashi Madrasa: A Case of Albanian Education System
}

\author{
Fatih Ufuk Bağcı \\ Chancellor at Beder University, PhD Candidate at European, \\ University of Tirana \\ email: fatihufukbagci@gmail.com
}

\section{Doi:10.5901/jesr.2014.v4n2p57}

\begin{abstract}
The present study aims to identify education, training activities, and the rehabilitating of the students with different lost values. As in many countries, many debates are scheduled about the importance and the role of these values which are lost values in education system in recent years in Albania. Therefore, a detailed examination is needed in the curricula and practices of education system to discover the values that should be gained by individuals and the differences in understanding or mentality about values. In this study, A research was made about the models of education structures that are used in Tirana Haxhi Mahmud Dashi Madrasa, in relation with it how we can equip respective students with the right understandings of values which are changing day by day depending on the changing of the world. The participants of this research are the teachers and students of Tirana Haxhi Mahmud Dashi Madrasa. In this study, both both qualitative and quantitative methods were utilized. At the same time the method of semi-structured interviews was used. In order to determine the subject, the school director, some teachers and students were interviewed and different discussions are made about the influence of this kind of activities on students. At the end of the study, the results demonstrate that the big role of extra-curricular activities in the development of universal and moral values of the students are put into practice in the education system of Tirana Haxhi Mahmud Dashi Madrasa. The limitation of this research was the effect and influence of these activities are limited, because the study was not focused on each and every student for measuring the degree of this effect. This research reveals that it is beneficial to introduce the importance of these activities in development of the system through considering as they are universal values among new generations and also they are being changed rapidly proportional to any change in the world. Therefore, the whole administrations should consider those values in order to put in the official curricula, and they should also organize and apply this kind of activities in order to give students a healthy and right mentality regarding universal values.
\end{abstract}

Keywords: Madrasa Education, Universal Values, Moral Values, Curricula

\section{Introduction}

Education is the name of the attitude taken against things that people encounter throughout life. There can be done very different definitions according to this meaning. For, every second of an average of 70 years of human life refers to education.

Education is the leading activity of changing human behavior. Is society's effort to transfer the culture, values and lifestyle to the new generation. These is not only an activity that is done in schools, it's a process that lasts a lifetime.

Socrates asserts that the purpose of education is to train non-dogmatic, non-prejudictive, open-minded,selfrighteous individuals in society, who believe in universal values and truths.

According to Plato the purpose of education is by educating good and honest citizens to achieve a society and state of justice. According to John Locke, the purpose of education is to educate people to progress happiness and wellbeing of the society. Good character comes from good breeding habits and virtuous actions. Ulusoy, K., et. al., (2012).

As in every science there is an objective, one of the most important objectives of education is the process of changing human behavior. If we would describe briefly the definition of education, we can describe it as the shaping and development process of behaviors, within the field of education, of an individual living in a society. Ulusoy, K., et. al., (2012) If this process is done in the framework of a specific plan it's called formal education, and if it's out of a plan it's called informal education.

Formal education is the education given in schools and school like educational institutions. Informal education is the education achieved by itself within the family or professional groups, without a plan or systematic. 


\section{Literature Review}

The word value is defined in many different ways. These definitions are derived from the Latin word "valere", which means "to be precious", "to be strong".

Values are the standards put by people to define the good, honest, beautiful and the ugly. In other words, they are the shared criteria and ideas indicating what social behaviors are good, right and deserved. Özkalp, E. (2005)

Value can be defined as abstract things such as manners, way of life, beliefs, covering all areas of life, that the members of the society pride thmeselves for having them.

Values are behaviors accepted and agreed upon by most of the people. In other words, they are beliefs and rules guiding our behavior. Oğuz, E. (2012).

Genç and Eryaman say that values are the generalized basic moral principles or beliefs, required and accepted by the majority of members to provide and accurate of their assets, unity, operation and continuation in a particular social group or community, reflecting their common feelings, thoughts, goals and interests. Genç, S. Z., et. al.,(2008.p.89-102).

The world in recent years is changing very quickly. Therefore our lives are changing too. As a result of this change topics related to us are changing according to the importance they have in our lives. People that experienced this rapid transformation show different ideas and attitudes in society.

The attitude varies from their quickly adaptation or non-adaptation. Changes due to technology are faster and easier to adopt. Bur changes due to our habits, character are more slowly and painful. Especially the way of life, habits and the language used between generations are very different.

Values education tries to educate individuals with international values and to prepare them for the likely potential problems. Doğan, I. (2007).

This project of worldwide proportions inspired by the new religious movement called the Brahma Kumaris World Spiritual University incorporates twelve values (unity, peace, happiness, hope, humility, simplicity, trust, freedom, cooperation, honesty, courage, love). The LVEP website lists 54 countries where values education projects are undertaken." Living Values Education" is supported by UNESCO.

According to Kirschenbaum values education helps to improve values. (1994: 14). Helps people to establish a satisfactory life. To help others is part of the nature of values education.

Values education aims to help others by transferring knowledge, skills, attitudes and values gained in educational institutions to them. Also aims contribution to the good of society and helping young people to live a more moral life and to be satisfied from their lives. "to want goodness and compassion for people and other living groups " are two objectives of values education. Ulusoy, K. (p.34).

\section{Discussion}

The value is the name of that what holds society together and makes life worth living. Value is what we feel it's absence when we lose it. Therefore, it's important the description and adoption to new generations. It should take it's neccesary place in both, family and social life, in an informal way, as well as should take place in formal education, getting applied in schools.

Since the creation of mankind there are experienced very serious changes, and we are still experiencing a process of changes following each other in every area. These one after another developments have led to certain changes in mankind. These developments have led to a change in the value judgments of people and in the perception of value. These developments are affecting human behavior and making difficult their adaptation to society. Social changes occurring as a result of developments in the scientific and technological field, are causing differences and problems in the perception of values in society. In this process, despite the rise in the living standards of humanity, on the other hand value problems arise and ultimately social structures are damaged.

This rapid change in the world, intensity and agressivity of the competitive environment, resort to many different methods in obtaining success, orientation from large families to small ones, childrens instead of having a physical contact with friends by the games they play in the street, they often stay away from parents attention, under the supervision of carers, brings as result a grown up sitting in front of the TV and living a non-social life.

As a result, there grow generations of pure self-interest, selfish, remote from love and sharing. In a society where the majority of the young generation is educated with this mentaliy, it will take both financial costs, as well as considerable time, to solve problems that may occur in family and society.

It's of a main importance to follow the developments and figure out according to what and how people shape their 
value judgements, thus to make right decisions about society and help new generations to gain values that can integrate them to society. Especially nowadays when compared to past periods there is a very serious development of the mass media, where written and visual publications have an important role in the constitution of human values.

Therefore, coping whit this changes and culture conflicts, can be gained to our new generations through helpful value models and an effectively and accurately planned education in schools or in different environments. The basic concept of this training and qualifying is the concept of value.

Albanian curriculum and assessment tools, reading and writing, memorizing, general understanding and so on are programmed to develop skills. Individual abilities, communication skills, teamwork, reasoning ability and imagination do not take part in curriculum and aren't measured in some way. Whilst in today's world and in business people are evaluated and taking a privileged status to such talents. Therefore, our curriculum and assessment tools should give place to this new values.

In modern societies where the responsibilities and functions of school became more important, another issue that needs a particular focus is the requirement to keep the essence of the culture of the society and to provide continuity. Of course, this society's value judgments are carried and adopted to new generations through education. In this period where everything is changing so rapidly, people see their life fading away in front of the wild waves. This values are the ones to save us from this raging waves and take us to the coast of salvation.

Fichter explains the functions that performing of values bring to society in the following way. Values:

a) Is used as an available tool for individual's and association's social value trial.

b) Focuses people's attention on objects of material culture seen as requested, useful and important.

c) Ideal ways of thinking and behaving are indicated by values.

d) Guide people in choosing and performing their social roles.

e) Direct individuals to make things right and refrain from non-approved behaviors.

f) Values also function as vehicles to solidarity between people that share similar values.

g) Meydan, H.(2012,p.14)

\subsection{What Are The Characteristics of Values?}

Values have a number of features according to their type and nature and according to their visibility and acceptance in society.

1. Cultures vary from community to community, according to cultures. Values in the same society can change over the time.

2. Values are behaviors that community appreciate. Dökmen,Ü. (2007.p.60)

3. Value is a belief : Rokeach specifying that values like all other beliefs, possess cognitive, affective and behavioral elements, lists the following attributes:

a. Value is an information-cognition related to desired (designed) and comprehention of desired. For a person to have a value, it means that cognitively he knows how to act properly.

b. Values are emotional, because a person has positive or opposite, confirmatory or opponent feelings that doesn't attend about it.

c. Values are behavioral, because when people take action, it has a feature that directs to behavior.

d. Values are truths that have costed to society. The form changing with the time constitute the basis of changes in the social structure. Ramazan, G. (2013.p.45-46).

\subsection{How values are classified?}

Although understanding of the common values of humanity, due to differences in societies and different cultures value classifications have been made. In studies on values there are five classifications generally accepted that attract attention. These; Values Inventory of Rokeach, Classification of Values of Morris, Classification of Values of Spranger, List of Values of Kahle and Theory of Values of Schwartz.

Bilgiseven classificates values differently, according to spiritual and material. Spiritual values are values like acuracy, helpfulness, that society esteems objectively and collectively. Bilgiseven, A. K. (1977).

According to another classification values are divided depending on if it's moral or not. Moral values include such as the respect to each other of people within the community, courtesy, keeping promises etc.

Values that are not moral do not carry such necessity. They express the values an individual wants and likes to do. 
For example the individual personally appreciates listening to classical music or reading good stories. But it does not have to do them all the time. ( Ramazan, G. Ü. (2013.p.50).

Spranger has divided the values into six main groups. These are: aesthetic, theorical (scientific), economic, political, social and religious value groups.

a. Scientific Value: It gives importance to truth, knowledge, reasoning and critical thinking. Human has scientific values and is experimental, critical, rational and intellectual.

b. Economic Value: It gives importance to useful and practical. Indicates that economic value needs to be heeded in life.

c. Aestethic Value: It gives importance to symmetry, harmony and shape. The individual sees life as a variety of events. Thinks of art is a necessity for society.

d. Social Value: It is essential to love others, help and not be selfish. The highest value is human love. This individual offers love to people. Is kind and sympathetic. Is not selfish.

e. Political Value: There is personal power, influence and fame above all. Mainly it's related to power.

f. Religious Value: Grasps the Universe as a whole and binds itself to its integrity. It sacrifices worldly pleasures for the sake of religion. Yazıcı, K., (2006.p.502).

According to Spranger another important person with a different view regarding values is Schwartz. According to Schwartz values are divided into individual and cultural. The values of the individual level, are treated according to their importance in guiding people's lives. The unit on a cultural level review is the cultural group (nations, ethnic groups) itself. Oğuz, E. (2012).

Çekin says that Schwartz by value intents beliefs.Values are associated with purposes of the individual and behaviors that are effective in reaching these objectives. Çekin, A. (2012).

Oğuz Schwartz indicates that in his studies he made studies determining the contents of value and created value's category. In Schwartz's Values Inventory was asked to make a choice of values from a 57 value list and and to list it according to it's importance in giving a direction to individuals lives.

Schwartz collected this data from 63 countries and approximately 60,000 people. Schwartz, at the result of this study divided these values into 10 value type in an individual level. These values are power, achievement, hedonism, stimulation, self-control, universalism, benevolence, tradition, conformity and security. Oğuz, E. (2012.p.1309-1325).

Ethem Başaran also makes a different value classification. According to him, values are structures changing depending on person and society member's acception. Social values are not equal in society in terms of nature, prevalence and power. In this respect, we can divide them into four. These:

1. Essential values; are important to the majority of community members and constitute the essence of culture, they are strong, core values. This change of values in society makes radical changes. For example, if the words constituting the essence of language are replaced by foreign words, language is disrupted.

2. Special values are used according to a locality, profession, according to subjects of interest. For example, teachers must act according to their profession's tradition and according to the values of the status community gives to them.

3. Optional values; are the values that are available anytime and anywhere for the members of society. This value is expected to be followed by the society, but when it's not followed the person is not condemned.

For example, today is not condemned when people get married without wedding. This applications are mostly related to compliance with the conditions.

4. Provisional values are values used a particular period of time, by a particular fraction of society, a followed fashion.

These values can come from other societies or can be created by a fraction of society. Are appreciated by the community, used for a certain period and then become invisible. As it's seen in the annual change of clothes. Çavdarcı, M. (2002.p.3).

\subsection{What are examples of Values Education?}

In various parts of the world is possible to see activities related to values education. In the following page we are going to touch upon activities made in Australia. There effective values education is realized in this form:

1. One of the objectives of Education in Australian schools is the improvement of attentiveness of students, respect, and values of cooperation.

2. To flourish consistent behaviours, outspokenness, by practicing in school. And to embrace the values of 
school and community.

3. To strengenth the relations between families and school community ( schoolboard, teachers, pupils ) by working in partnership with pupils.

4. Pupils should be supported during their education, we should help them discover themselves, give them security must ensure them that their own values are in the same time the values of school and the entire community. Ulusoy, K.\& Dilmaç B. (p.35)

For example in America in 1995 was prepared a program under the name " Values Education Program" which initiated "The call to values". A program that tried to fight the diseases of our century like increasing of violence worldwide, social problems, lack of respects for others. Oğuz, E. (2012.p.1311).

\subsection{What Are The Objectives of Values Education?}

Discovering people innate abilities, revealing their angelic direction, provide development in all of the aspects of their personality are the objectives of values education. That's why we must provide them with accurate information about proper and improper manners and behaviours. If this is done development of their good trends from their disposition will happen and stable resting against evil tendencies will be easier.

The training activities are applied in schools for a certain number of objectives. It may change a little from a school to another but generally education objectives are the same. The objectives are as follow:

1. Education of individuals in accordance with the understanding of the overall values of the community

2. Education of benignant individuals for community and the entire humanity.

3. To help self-recognition

4. Recognition of the ability of people and aspects of being useful to society

5. Education of morally mature, with good character, good conscience and unselfish individuals.

6. Having a values thinking based on tolerance.

7. Education of environmentally conscious citiziens, etc.

\subsection{How values education should be given?}

Values education consists of a number of mutually supportive elements. For more healthy upbringing generations these elements must be coordinated. Any lack or imperfection in these elements effects the success of education activities.

1. School activities

2. Class activities

3. Activities that must be done by family

\subsubsection{School activities}

In recent years different countries have included values education in their education curriculum. Various activities were made to teach pupils national and international values. Activities related to the development of practical applications has begun. These education program includes topics like love, respect, honesty, sharing, cooperation, tolerance, cleanliness, refrain from violence, helping those in need.

Many vital issues are gone with the effect of modern life. Parents struggle to teach these moral values to their children. The program and activities makes improvement possible.

Oğuz related to the values that should be taught in schools has proposed different ones. This was as a result of research. Oğuz, E. (2012). Bennet proposes values like pity, self-control, responsibility, friendship, work, courage, courage, resistance, honesty, sincerity. Ryan proposes values like justice, prudence, temperance, courage, confidence, hope, kindness, sense of duty. Responsibility, respect, tolerance, common sense, self-control, compassion, cooperation, courage, honesty, justice and democratic values are proposed by Lickona. Oğuz, E. (2012.p.1312).

After the school values education programs and activities, implement of activities are also needed mechanism that would help supporting activities and program. Also these mechanisms will recommend keeping the rules.

Seminars and presantations should be organized to administrators, teachers and pupil groups who should promote values education.

Teachers, pupils and parents must be informed about activities. They can be informed by school newspaper, school website, billboards, banners, and weekly or monthly school newspapers. 
Also activities about values education should be part of school club activities curricula.

The attention of the persons concerned in this matter or media can be attracted by common activities with wellknown personalities from the arts and media community or sports.

\subsubsection{Class activities}

In all grades one or more representative must be elected. The elections will make the organizations more fruitful. The organizations in other hand will improve pupils individual and social responsibility.

Classroom activities that will be held in a year must be arranged in parallel with the curriculum. This arrangement plays a complementary role in learning.

Development of students' communication activities, training and education activities on behalf of socialization along with the execution of such activities is important.

Things that must be done for an effective values education:

1. Helping others, understanding pupils and implement of care and compassion values. To adopt them such values as to make the best, to act honestly, trustworthiness, integrity, respect, responsibility and tolerance.

2. Teacher's objective must be: improvement of life and democratic structure in Australia and value the diversity in Australian schools.

3. The school should be open to the values society. Schools should be able to enforce these values in a consistent manner.

4. To gather students and school staff, school staff ( parents and school community ) must think what to do to transfer the responsibility to implement and strengthen the flexibility of values.

5. To help pupils discover themselves and encourage them, to explain to them in the best way that school and community has values.

6. Different models, forms and strategies must be shown to teachers and then deliver to them the most appropriate trainings tools and resources.

7. Applicable approaches in values education must be analized whether meets or not with the results.

Australian government schools teaches learning support values and including values.At the same time these schools gives to student the opportunity to explore values on political and social issues behind various social attitudes.Ulusoy, K., \& Dilmaç, B. (2012,p.35).

In the center of values education are teachers. They perform education. Consequently, teachers before performing must be informed about a number of issues. Also must be required from them to undergo certain training. By Ulusoy in education of values, teacher needs to know the issues that are listed as follow:

a. Be a model,

b. In the classroom should create a "common social fabric",

c. By giving each responsibility, should contribute to the development of their moral.

d. Encourage pupils, by using penalizing values can be taught.

e. Pupils should recognize the possibility of deciding,

f. Pupils should be given the opportunity to share,

g. Should be encouraged to work in partnership,

h. Discussion and sharing environment should be created..Ulusoy,K.,\& Dilmaç, B. (2012,p.36).

\section{Research Problem}

In this research, we have been using the qualitative research method in order to make clear the usefulness of our school. These researches are the ones that use techniques such as survey, meetings, document analysis, information gathering etc. Yazar,T. (2012.p.61-68).We have been trying to find solutions the following problems:

1. What kind of behavior model do the activities we are organizing on value education represent?

2. What are the purposes of these activities for our beloved Albania?

\subsection{The purpose and importance of research}

The purpose of this research is to analyze the activities organized under the name of value education. Such activities are held inside our schools environments as well as outside. On the other hand, it defines the way in which other institutions 
might use these values for further good of the Albanian education.

\subsection{The content of research}

Research has been made about education values at Tirana Haxhi Mahmud Dashi Madrasa in the period in an academic year in 2013-2014. These activities have taken place within the school surroundings while the rest has taken place abroad in collaboration with various organizations that are in town.

\subsection{The collection data-info}

Technique is used as a method of meeting and analysis of documents. In the technique of meeting or conversation that is one of Qualitative research in most cases relies on communicating with words, individual perspectives, experiences and feelings of people. (Kaymakcan,R.,2012)

\subsection{The research method}

This method has benefited from the qualitative researches in the definition of the references, in the gathering of information as well as in the processes of analysis.

\section{The Values Education Activities Held in Tirana Madrasa}

Albania before meeting democracy was formerly closed to the outside Europe. After meeting with democracy it had a structure looking for ways to integrate with modern world.

In recent years, by winning the right to move free within the European Union Albanian integration to Europe has made significant progress towards. However, these positive developments has emerged different aspects which are nowadays spoken among people who are not very hopeful about improvements. Issues such as unrest among families, divorces, violence against women etc. has frequently emerged in TV news. In fact, Albanian People analyses very good the changes that occurred in the structure of society in a short time and cannot give a meaning to all this.

Despite the fact that has a rise in the number of divorces, family is a very important human value in Albania. So contradictory. Women are crowns but we see everyday how many exercise of violence occurs. People do not pay attention to cleanliness of the streets, the people at a certain age and in responsible positions are disturbed by what we mentioned.The main issues to be discussed here is how this trend will be controlled and how the new generation can be grown up better. In the whole world a single response can be given to this question: Education.

According to Genç and Eryaman respond to the evolving trends of the information society of today and schools are in need for a new face and identity. Educated people are the largest capital of information society. Schools as institutions have the potencial to shape people. That's why the content and objectives of schools must be rethought. Genç, S. Z., \& Eryaman, M. Y. (2008).

If training programs are shaped in accordance to needs of generation and requirements of the age the success of these programs is very high. Nowadays dynamic, practical life convenient training programs are preferred more than static ones. Technology and society with the alteration of the structure brought out changes to programs. Programs themselves are up to these changes.

Those who did not plan or implement the changes cannot get rid of characterized as others. With the increasing number of these products their behavior, understandings are going to be considered normal. In this way community changes without requests.

Still Genç ve Eryaman starting that information is everywhere, they say that it is not possible to confine the boundaries of certain institutions express. Therefore, we must transfer knowledge of the schools from just transferring information into generating information institucions. This generating information will improve analyze and problem solving skills at individuals. Genç, S. Z., \& Eryaman, M. Y. (2008).

Therefore, in Albania as it is in the whole world is essential for Albanian education system to grow bodily and mentally health balanced pupils, who have independent and sturdy frame of mind, and are respectful to human rights and universal values, aware of responsibility for their nation and society.

In line with this aim and ideal, schools organize and implement training programs. As stated above, schools and teachers have a big responsibility. They must protect our values that in recent years are leading to extinction, and must 
transfer these values in a healthy way to new generations.

Tirana Haxhi Mahmud Dashi Medrasa is realizing the planning of dynamic program as well as their application in practice. Education at this school more than a simple educational activities aimed achieving the target behavior which consists of planning and implementation. School activities are organized into" Weeks" logic. Ex: History week, Environmental week, Languages week etc. When the relevant week in the annual activity planning comes planning staff person, group or classes schedules a variety of events for 5 days.

Located in the position of deputy director at school in the beginning of the new year as of the beginning of the planning and practices aims to help pupils to become individuals integrated into society, harmonious, loving environment.

These activities are given below with an outline.

These activities are shortly given below.

\section{Activities that Give Social Responsibility.}

a. Visiting hospice nursing. The students of "Tirana Haxhi Mahmud Dashi" madrasa visit the hospice nursings of the city and give presents to old people who live there. The aim of this activity is to give to students the feeling of responsibility and to make the old people feel themselves as a part of this community where each of us take part. After taking permission from the administration of the hospice nursing, the students perform a short show with songs and plays. By this way, the residents of the hospice nursing enjoy a different day in their lives.

b. Visiting the orphanages. Another activity is similar to the first one, to provide the integration between students and orphans.

c. We tried to share their sadness and joy by performing competitions, singing songs all together, playing games and giving presents to each of them. Mr. Unal, our English teacher, during the last two years showed a great model of sacrifice by sending to the orphanages the remaining foods which were prepared for our students. Even his students helped him during this activity, so they were a part of this social responsibility project.

d. Give the hand of help. Is a programme that aims to help poor families by using the students and the help of class teachers. The students were informed about this activity, and after that the organizer committee was founded by the students and the teachers. Then the activity was explained to everyone in the school, by this way each one could be part of this activity by giving a hand of help for poor families. Generally these donations were foods and clothes. With the help of the municipality of the town poor families were identified and finally the donations were delivered.

e. Do not forget your brother. Donating blood for patients of leukemia by cooperating with the authorized people of The Red Cross of Albania is another activity of our school students who have the permission of their families for doing this. By being part of these activities the students become conscious of being a helpful individual of this society.

\section{Activities that AIM Environmental Awareness.}

a. My environment. One of the most important problems in Tiran is environmental cleanliness. Tirana Haxhi Mahmud Dashi Madrasa tries to make possible students being conscious about the importance of environmental cleanliness. So, every term of our students clean the roads and the places where they live. At the same time articles about the importance of this activity are prepared.

b. A Green World. The director of the Tirana Haxhi Mahmud Dashi Madrasa,Ömer Çalış starts to explain the activities with the words of the Prophet Muhammad. "Plant the tree if you have time, even during the doomsday".Ahmed b. Hanbel, Müsned, III, 184, 191.For this reason, the activities are very important for the students of Tirana Haxhi Mahmud Dashi Madrasa, to plant trees and protect green. Due to the fact that "a green world" is a new project, for this reason at the beginning, the school has organized an essay contest about the love of the tree; protecting green etc.The school has also displayed pictures and poems about a green world in order to draw the students' attention. As a symbolic, the students have planted trees to the school yard at the beginning of the week.

\section{Activities Towards Values}


a. Dear teacher, dear mother. Due to the important values of teachers and parents, teacher's and mother's days are celebrated during the two days. In Albania the $7^{\text {th }}$ march is celebrated as a teacher's day and the $8^{\text {th }}$ march is celebrated as a woman's day. That is why; it is possible to see pictures at the school during these days which describe the importance of mothers and teachers. That week, a programme is organized and the female staff and the female personnel are given presents. The retired teachers and personnel are visited, who worked before at this school. Regarding the importance of being teachers and mothers, dramas are played and articles are read.

b. Love for the country, the week of the history. For the state and country love, in order to represent the beauty of Albania, a history week and geography week is organized. During these weeks the students display the folk dances that belong to their regions, they dress their regional costumes and they also show their regional food and meals. Besides, they also demonstrate their regional traditions. I also attended one of the programmes. They showed how the engagement and weeding ceremony arranged in the north part of Albania. These activities remind the people and the students of the beauty of those forgotten ceremonies.

c. I like languages. Currently, the education is given in three languages at the Tirana Haxhi Mahmud Dashi Madrasa. The science subjects in English, some social subjects in Albanian and the religion subjects are taught in Turkish. The school principal states that languages are very important due to the fact that languages are very essential at this school. For this reason, twice a year language weeks are organized at the school.

Some activities are done during these weeks such as: seminars, competitions and sketches. The principal again states that one can only see languages activities within that week, they invite the state schools, at the same time they do some activities together. The principal continues stating that such activities draw students attention towards languages. Languages are important instruments among people in order to communicate and to have dialogues and the students present what they learn and they also gain their self confidence.

d. My dear book. In order to make the students gain the reading habits and love of the reading, during some periods of the year, students read books for 15 minutes under the supervision of the teachers before the first lesson starts in the morning.

On the other hand, sometimes at the end of the term and sometimes during the holidays the students come together under the supervision of the teachers and the students read books and they also discuss the read books. We can also say that the teachers record the number of books that the students read and spend time on reading. This is another kind of activity.

e. To be an examplary. The most effective method in the education is visual learning. This kind of learning has a direct relation with the human nature. The most important social theory of learning is learning from the modeling. We can claim that the most important difference of the teachers of the Tirana Haxhi Mahmoud Dashi Madrasa, is being a model towards the students.

Well, during our interviews we focused on the fact that the teachers inside the school and outside the school should follow the principles.

According to the teachers a model teacher is like in the position of a prophet. The living style of prophets have been taken an example from the people or they pay attention to the living style of prophets (their influence on people come from this and they always lead an exemplary life).That is why, the teachers, who take such responsibilities, should have such life and behaviors in order to be more effective on the students.

Tirana Haxhi Mahmud Dashi Madrasa Administrators and teachers, before beginning their operations on education values, have come to a consensus in the following way. Before making activities, to teach students certain values, to turn them into their behavior, they believed in the necessity to manifest an exemplary behavior should be within the school, or outside the school. Their persistence in their learning model was stemmed by the important thinker of the Islamic world Fethullah Gülen's idea that a movement which is " Examples from himself" has a higher chance of being successful.

On the other hand, for the development and persistence of the values of family members and all school employees, always the same attitudes and behaviors are required to be exhibited in a"consistent"format.

To do this, we should provide that students, primarily educators and all staff, are believed to be right, good and trusting people. During education, the love and trust shown to the child, will give comfort to the educators as well as to people who are to be educated. According to the studies, a person, in order not to lose the love and trust of a loved one or someone who loves him, they should firstly like his behavior.

In the event of the continuation of this, that person, in time, should develop his personality in a direction that they would desire. Of course, in the opposite case, the child, as he continues his undesired behavior, 
sometimes is able to make the opposite of what people he doesn't like tell him to do. Aydın,M.Z.(2010).

f. Organizing activities describing the lives of exemplary people. The teachers described above schedule campaigns to watch movies telling the lives of people who lived in Albania or abroad that lived for or were useful to mankind, theatrical productions and read novels. In this way, people who live their lives in pursuit of a value will serve as good examples and are believed to contribute positively to education activities. (Watching "The Green Way" cinema or Gandhi Movie, etc.)

\section{Conclusion and Findins}

As a result, the period in which we live, is a period with rapid changes, a period in which changes that took years in the earlier centuries occurring a very short time. Social changes that are known by us as a general law are the longest changes.

But nowadays, within a very short time, many social changes take place in an average human life. Especially in societies that are new to this development, these changes are experienced much faster. We are living up to these changes, from the music we listen to our way of life, from some of our traditions to human relations.

For the process of change cannot be avoided, what we should do is make it more controlled. One of the most appropriate places for this to be done is the schools. In particular the education system of the period until the end of high school is very important in the growth of our generation. The education is given and the behavior is gained in these years, at older ages the personality of the person is formed. This can be considered as a foundation. Those with a better foundation will be able to choose more accurate directions on changes that have a probability of $100 \%$ the future.

Therefore, the governments have a serious role in the determination of the curriculum and the upbringing and training of teaching staff according to this curriculum. Governments setting aside their personal political thinking should emphasize non-populist programs that society needs and raise their generation solidly.

When preparing the curriculum, for each course according to the nature of that course, we should be focused on the behavioral attitudes to be transmitted to the students, giving books etc. Activities should be determined this way. Implementing thoughts like this to our lives, our generation will be able to protect itself against the ruthless change of time; they will be able to select the most appropriate way for themselves.

\section{References}

Bilgiseven, A. K. (1977). Türk milletinin mânevi değerleri (Vol. 2). Millî Eğitim Basımevi: dağııım yeri, Devlet Kitapları Müdürlüğü.

Çavdarcı, M. (2002). Türkiye'de sosyal değerlerin aşınması ve kültür sömürgeciliği (Doctoral dissertation, Sosyal Bilimler).

Çekin A.(2012).Değer Açısından İlköğretim Din Kültürü ve Ahlak Bilgisi Dersi Kazanımları: Bir İçerik Analizi. Dinbilimleri Journal,12(2).

Doğan, İ. (2007). Türk eğitim sisteminde değer sorunu. Değerler ve Eğitimi Sempozyumu Bildiri Kitapçığı,(syf. 615-634). İstanbul: Dem Yayınları.

Dönmezer, S. (1990). Sosyoloji İstanbul. Beta Yayını, 118.

Meydan,H. (2012). Illköğretim Okullarında Değerler ve Karakter Eğitimi Doktora Tezi.

Oğuz, E. (2012). Öğretmen adaylarının değerler ve değerler eğitimine ilişkin görüşleri. Kuram ve Uygulamada Eğitim Bilimleri (KUYEB)Değerler Eğitimi Sempozyumu Ek Özel Sayısı, 12(2), 1309-1325.

Özkalp, E. (2005). Davraniş Bilimlerine Giriş (Vol. 1355). Anadolu Üniversitesi.

Ramazan, G. Ü. L. Bir deger egitimi olarak ilköğretim döneminde dogruluk egitimi.Yüksek Lisans Tezi.Çorum,(2013).

Silah, M. (2005). Sosyal psikoloji: davranış bilimi. Seçkin.

Ulusoy, K., \& Dilmaç, B. (2012). Değerler Eğitimi. Ankara: Pegem Akademi.

Üstün Dökmen, Küçük Şeyler, Sistem Yayıncılık, İstanbul 2007, s.60 .

Yaızıcı K.Değerler Eğitimine Genel Bir Bakış.Tübar,2006, C. 19, s.502.

Coşkun,Y. \& Yıldırım, A.Üniversite ogrencilerinin deger duzeylerinin bazi degiskenler acisindan incelenmesi. Yüzüncü Yıl Üniversitesi, Eğitim Fakültesi Dergisi. Haziran 2009. Cilt:V1, Sayı:I, 311-328. 